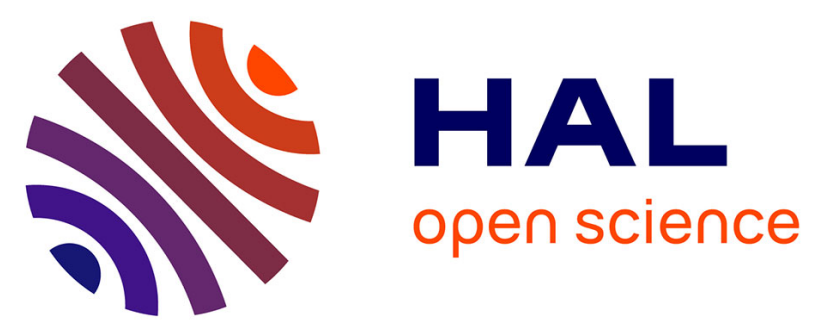

\title{
Preparation of chains of magnetosomes, isolated from AMB-1 magnetotactic bacteria, yielding efficient treatment of tumors using magnetic hyperthermia
}

Edouard Alphandéry, François Guyot, Imène Chebbi

\section{- To cite this version:}

Edouard Alphandéry, François Guyot, Imène Chebbi. Preparation of chains of magnetosomes, isolated from AMB-1 magnetotactic bacteria, yielding efficient treatment of tumors using magnetic hyperthermia. International Journal of Pharmaceutics, 2012, 434 (1-2), pp.444 - 452. 10.1016/j.ijpharm.2012.06.015 . hal-01547081

\section{HAL Id: hal-01547081 \\ https://hal.sorbonne-universite.fr/hal-01547081}

Submitted on 26 Jun 2017

HAL is a multi-disciplinary open access archive for the deposit and dissemination of scientific research documents, whether they are published or not. The documents may come from teaching and research institutions in France or abroad, or from public or private research centers.
L'archive ouverte pluridisciplinaire HAL, est destinée au dépôt et à la diffusion de documents scientifiques de niveau recherche, publiés ou non, émanant des établissements d'enseignement et de recherche français ou étrangers, des laboratoires publics ou privés. 


\section{Preparation of chains of magnetosomes, isolated from}

13 Adresse: Nanobacterie, 36 boulevard Flandrin, 75016, Paris, France.

14 No fax.

*CORRESPONDING AUTHOR CONTACT DETAILS:

E-MAIL edouardalphandery@hotmail.com

Phone: 33632697020.
AMB-1 magnetotactic bacteria, yielding efficient treatment of tumors using magnetic hyperthermia
${ }^{+}$Institut de minéralogie et de physique des milieux condensés, Université Pierre et Marie Curie, UMR CNRS 7590, 4 Place Jussieu, 75005, Paris.
${ }^{\perp}$ Nanobacterie SARL, 36 boulevard Flandrin, 75016, Paris.
xUniversité Paris Diderot, Sorbonne Paris Cité, Institut de Physique du Globe de Paris, 1 Rue Jussieu, 75005, Paris

15

16 
Chains of magnetosomes isolated from AMB-1 magnetotactic bacteria by sonication at $30 \mathrm{~W}$ during 2

19 hours are tested for magnetic hyperthermia treatment of tumors. These chains are composed of 20 magnetosomes, which are bound to each other by a filament made of proteins. When they are incubated

21 in the presence of cancer cells and exposed to an alternating magnetic field of frequency $198 \mathrm{kHz}$ and 22 average magnetic field strength of 20 or $30 \mathrm{mT}$, they produce efficient inhibition of cancer cell 23 proliferation. This behavior is explained by a high cellular internalization, a good stability in solution 24 and a homogenous distribution of the magnetosome chains, which enables efficient heating. When the 25 chains are heated during 5 hours at $90{ }^{\circ} \mathrm{C}$ in the presence of $1 \%$ SDS, the filament binding the 26 magnetosomes together is denatured and individual magnetosomes are obtained. By contrast to the 27 chains of magnetosomes, the individual magnetosomes are prone to aggregation, are not stable in 28 solution and do not produce efficient inhibition of cancer cell proliferation under application of an 29 alternating magnetic field.

KEYWORDS

37 Magnetosomes, magnetotactic bacteria, cancer, tumor, chains of magnetosomes, individual 38 magnetomes, alternating magnetic field, magnetic hyperthermia. 
Magnetic hyperthermia is a technique by which magnetic nanoparticles are either introduced or sent

41 within tumors and heated under the application of an alternating magnetic field (AMF). The heat

42 produced locally by the nanoparticles induces anti-tumoral activity. Magnetic hyperthermia has been

43 used both on animal models and on humans to treat a series of different cancers, including breast cancer,

$44[1,2]$, prostate cancer, [3-6], glioblastoma, [7], and head and neck cancer, [8]. Until now, most of the

45 iron oxide nanoparticles tested were chemically synthesized with either a superparamagnetic or a weakly

46 ferrimagnetic behavior at physiological temperature, [9-12]. For an applied magnetic field of frequency

47 and strength kept below a toxicity threshold of $\sim 200 \mathrm{kHz}$ and $\sim 100 \mathrm{mT}$ respectively, [13], the specific

48 absorption rate (SAR) of the chemically synthesized nanoparticles is lower by a factor of 2 to 100 than

49 that of the biologically synthesized nanoparticles, called magnetosomes, [9-11]. For this reason, there

50 has been a surge of interest to carry out magnetic hyperthermia for cancer treatment using the

51 magnetosomes, [14-18]. In fact, the magnetosomes are monodomain, well-crystallized nanoparticles

52 surrounded by a lipidic membrane with the unique property of being usually arranged in chains. They

53 are synthesized by a species of bacteria, called magnetotactic bacteria, which use them as a compass to

54 navigate in the direction of the earth magnetic field in search for an optimum environment. In a previous

55 study, [18], $1 \mathrm{mg}$ of a suspension of chains of magnetosomes extracted from AMB-1 magnetotactic

56 bacteria has been administered within breast tumors xeno-grafted under the skin of mice. After three

57 applications of an alternating magnetic field during 20 minutes, tumors were totally eradicated in several

58 mice. These results suggest that chains of magnetosomes extracted from AMB-1 magnetotactic bacteria

59 are highly efficient for solid tumor treatment using magnetic hyperthermia, [18].

60 In this article, we examine if the efficiency of chains of magnetosomes extracted from AMB-1

61 magnetotactic bacteria, designated as CM, is solely due to the high SAR of the magnetosomes or if it

62 also arises from other factors such as a homogenous distribution of the magnetosome chains within the

63 tissue or a faculty of the magnetosome chains to internalize within the cancer cells. To know the 
influence of the magnetosome chain arrangement on the efficiency of the therapy, we compare the

65

66 properties of the chains of magnetosomes with those of individual magnetosomes, designated as IM, which are detached from the chains by heat and chemical treatments.

\section{MATERIALS AND METHODS}

\subsection{Method used for the culture of the AMB-1 magnetotactic bacteria:}

Magnetotactic bacteria belonging to the species Magnetospirillum magneticum, strain AMB-1, available at the ATCC under the reference 700264, were cultivated in a volume of 1 liter of bacterial growth medium. The cells were cultivated in micro-anaerobic conditions, $i$. e. in a culture medium that has not been degassed, but is closed and not in contact with oxygen. The culture of magnetotactic bacteria has been carried out in an incubator at $26^{\circ} \mathrm{C}$ in a slightly modified MSGM liquid culture medium, whose composition is described below.

For a volume of 1 liter, the standard culture medium contains $0.68 \mathrm{~g}$ of monobasic potassium phosphate, $0.85 \mathrm{~g}$ of sodium succinate, $0.57 \mathrm{~g}$ of sodium tartrate, $0.083 \mathrm{~g}$ of sodium acetate, $225 \mu \mathrm{l}$ of $0.2 \%$ resazurine, $0.17 \mathrm{~g}$ of sodium nitrate, $0.04 \mathrm{~g}$ of L-ascorbic acid, $2 \mathrm{ml}$ of a $10 \mathrm{mM}$ solution of iron quinate, $10 \mathrm{~mL}$ of a solution of Woolf's vitamins and $5 \mathrm{~mL}$ of a solution of Woolf's minerals. The solution of iron quinate has been prepared by dissolving $0.19 \mathrm{~g}$ of quinic acid and $0.29 \mathrm{~g}$ of $\mathrm{FeCl}_{3} .6 \mathrm{H} 2 \mathrm{O}$ in $100 \mathrm{ml}$ of distilled water. The solution of Woolf's minerals contains in 1 liter of distilled water, $0.5 \mathrm{~g}$ of nitrilotriacetic acid $\left(\mathrm{NTA}, \mathrm{C}_{6} \mathrm{H}_{9} \mathrm{O}_{6}\right), 1.5 \mathrm{~g}$ of magnesium sulfate heptahydrate $\left(\mathrm{MgSO}_{4} .7 \mathrm{H}_{2} \mathrm{O}\right), 1 \mathrm{~g}$ of sodium chloride, $0.5 \mathrm{~g}$ of manganese sulfate monohydrate $\left(\mathrm{MnSO}_{4} \cdot \mathrm{H}_{2} \mathrm{O}\right), 100 \mathrm{mg}$ of iron sulfate heptahydrate $\left(\mathrm{FeSO}_{4} .7 \mathrm{H}_{2} \mathrm{O}\right), 100 \mathrm{mg}$ of cobalt nitrate heptahydrate $\left(\mathrm{Co}\left(\mathrm{NO}_{3}\right)_{2} .7 \mathrm{H}_{2} \mathrm{O}\right), 100 \mathrm{mg}$ of calcium chloride $\left(\mathrm{CaCl}_{2}\right), 100 \mathrm{mg}$ of zinc sulfate heptahydrate $\left(\mathrm{ZnSO}_{4} .7 \mathrm{H}_{2} \mathrm{O}\right), 10 \mathrm{mg}$ of copper sulfate pentahydrate $\left(\mathrm{CuSO}_{4} .5 \mathrm{H}_{2} \mathrm{O}\right), 10 \mathrm{mg}$ of aluminium potassium sulfate, $10 \mathrm{mg}$ of potassium dodecahydrate $\left(\mathrm{AlK}\left(\mathrm{SO}_{4}\right) \cdot 12 \mathrm{H}_{2} \mathrm{O}\right), 10 \mathrm{mg}$ of boric acid $\left(\mathrm{H}_{3} \mathrm{BO}_{3}\right), 10 \mathrm{mg}$ of sodium molybdate dehydrate $\left(\mathrm{Na}_{2} \mathrm{MoO}_{4} \cdot 2 \mathrm{H}_{2} \mathrm{O}\right), 2 \mathrm{mg}$ of sodium selenite $\left(\mathrm{Na}_{2} \mathrm{SeO}_{3}\right), 10 \mathrm{mg}$ of sodium tungstate dihydrate 
$\left(\mathrm{Na}_{2} \mathrm{WO}_{4} \cdot 2 \mathrm{H}_{2} \mathrm{O}\right)$ and $20 \mathrm{mg}$ of nickel chloride hexahydrate $\left(\mathrm{NiCl}_{2} \cdot 6 \mathrm{H}_{2} \mathrm{O}\right)$. The solution of Woolf's

vitamins was prepared by dissolving in one liter of distilled water, $2.2 \mathrm{mg}$ of folic acid (vitamin B9),

$10.2 \mathrm{mg}$ of pyridoxine (vitamin B6), $5.2 \mathrm{mg}$ of riboflavin (vitamin B2), $5.2 \mathrm{mg}$ of pantothenic acid

91 (vitamin B5), $0.4 \mathrm{mg}$ of vitamin B12, $5.2 \mathrm{mg}$ of amino-benzoic acid, $5.2 \mathrm{mg}$ of thiotic acid and $900 \mathrm{mg}$

of potassium phosphate. The $\mathrm{pH}$ of the culture medium was adjusted to 6.85 by using a $1 \mathrm{M}$ solution of sodium hydroxide.

2.2 Preparation of the different suspensions containing the extracted chains of magnetosomes and individual magnetosomes:

Two different types of magnetosomes have been isolated from AMB-1 magnetotactic bacteria, those arranged in chains and those forming individual nanoparticles. To prepare them, the cells were first were re-suspended in deionized water. To extract the chains of magnetosomes, $1 \mathrm{ml}$ of cell suspension obtained as previously described was centrifugated again and re-suspended in a $10 \mathrm{ml}$ tris-HCl buffer of $\mathrm{pH}$ 7.4. The cellular suspension was then sonicated during 120 minutes at $30 \mathrm{~W}$ in order to lyse the cells and collect the CM. After sonication, the suspension containing the CM was separated from the cellular debris by positioning a strong neodynium magnet $(0.1-1 \mathrm{~T})$ next to the tube, and the magnetic material was then harvested. The supernate containing the cellular debris and other organic molecules was eliminated. CM were washed 10 to 20 times in deionized water at $\mathrm{pH} 7.4$ and were then resuspended in deionized water. To prepare the suspensions containing the IM, the suspension containing the CM was

107 heated during five hours at $90{ }^{\circ} \mathrm{C}$ in the presence of $1 \%$ SDS. IM were separated from the biological 108 material remaining after the treatment by using a strong neodynium magnet $(0.1-1 \mathrm{~T})$. The concentrations 109 in maghemite of the various suspensions containing CM and IM were measured by absorption at 480 $110 \mathrm{~nm},[18]$.

1112.3 Methods used for measuring the SAR and for heating the different suspensions of bacterial magnetosomes: 
113 The SAR of suspensions of CM and IM were measured for bacterial magnetosomes, which were either

114 able or unable to rotate under the application of an AMF, [16]. The amount of heat produced in the gel

115 by the CM and IM was low under the application of an AMF of frequency $108 \mathrm{kHz}$ and magnetic field 116 strength kept below $36 \mathrm{mT}$, [16]. To enhance the magnetosome heating efficiency during the in-vitro 117 and in-vivo heating experiments, the frequency of the AMF was therefore increased up to $198 \mathrm{kHz}$ and 118 the average magnetic field strength was kept below $30 \mathrm{mT}$ to avoid the formation of eddy currents, 119 which can induce toxicity. The average magnetic field strength was estimated from the variation with 120 time of the magnetic field strength. It was measured using a 2D magnetic field probe designed by the 121 company Fluxtrol. The value of the average magnetic field strength measured experimentally with this 122 probe was 1.8 times lower than the theoretical value of the magnetic field, estimated using the relation B $123=\mu_{0} \mathrm{NI} / \mathrm{L}$, where $\mu_{0}=4 \pi 10^{-7}$ is the vacuum permeability, $\mathrm{N}=4$ is the number of spires in the coil, $\mathrm{I}=$ $124151,300,419$ or $600 \mathrm{~A}$ is the amplitude of the alternating current flowing through the spires and $\mathrm{L}=3.5$ $125 \mathrm{~cm}$ is the length of the coil (Suppl. table 1). The temperatures reached during the heating experiments 126 were measured using a thermocouple microprobe (IT-18, Physitemp, Clifton, USA). presence of the different suspensions of magnetosomes isolated from AMB-1 magnetotactic bacteria:

The HeLa and MDA-MB 231 cells were purchased from the ATCC. The cell lines were cultivated in 130 Dulbecco's model modified Eagle's medium supplement, which contained 10\% fetal calf serum, $2 \mathrm{mM}$ 131 L-glutamine, $1 \mathrm{mM}$ sodium pyruvate, and $50 \mathrm{U} / \mathrm{mL}$ streptomycin (all purchased from Life Technologies 132 Inc.). Cell viability was evaluated using the so-called MTT (microculture tetrazolium) assay, [19]. This 133 technique measures the ability of mitochondrial enzyme to reduce 3-(4,5-dimethylthiazol-2-yl)-2,5134 diphenyltetrazolium bromide (purchased from Sigma, St Louis, MO, USA) to purple formazan crystals. 135 MDA-MB-231 and HeLa cells were seeded at a density of $2.10^{4}$ cells per well in 96-well flat-bottom 136 plates (Falcon, Strasbourg, France) and incubated in completed culture medium for 24 hours. Then, the 137 culture medium was removed and replaced by $10 \%$ FCS-medium containing CM or IM with different 
concentrations in iron oxide $(1 \mathrm{mg} / \mathrm{mL}, 500 \mu \mathrm{g} / \mathrm{mL}$ or $125 \mu \mathrm{g} / \mathrm{mL})$. After 24 hours of incubation, the cells were exposed (or not) to an AMF of frequency $198 \mathrm{kHz}$ and average magnetic field strength of $20 \mathrm{mT}$ or $\sim 30 \mathrm{mT}$ during $20 \mathrm{~min}$. After having been exposed to the AMF, the cells were incubated at 37 ${ }^{\circ} \mathrm{C}$ in a $5 \% \mathrm{CO}_{2}$ humidified atmosphere during 48 hours. Following the incubation, cells were washed with phosphate buffered saline solution (PBS, Life Technologies) and incubated with $100 \mu$ l of MTT (2 $\mathrm{mg} / \mathrm{ml}$, Sigma-Aldrich) for an additional 4 hours at $37^{\circ} \mathrm{C}$. The insoluble product was then dissolved by addition of $100 \mathrm{ml}$ of DMSO (Sigma-Aldrich). The absorbance of the solubilized formazan pellet, which reflects the relative viable cell number, was measured at $540 \mathrm{~nm}$ using a Labsystems Multiskan MS microplate reader. The measurements were carried out on DMSO solubilized formazan pellets using cells washed with PBS as a control, [20]. The experiments were carried out in triplicates.

\subsection{Internalization and magnetization studies of MDA-MB 231 cells incubated in the presence of} various suspensions of magnetosomes:

$5.10^{5}$ MDA-MB-231 cells in suspension were mixed in $1 \mathrm{ml}$ of a $10 \%$ FCS-medium containing suspensions of CM or IM with a fixed concentration in iron oxide of $1 \mathrm{mg} / \mathrm{ml}$. The cells were exposed (or not) to an AMF of frequency $198 \mathrm{kHz}$ and average field strength of $\sim 20 \mathrm{mT}$ during 5, 10, 15 and 20 minutes. Following the application of the AMF, the MDA-MB-231 cells were collected with a strong neodynium magnet $(0.1-1 \mathrm{~T})$. For each sample, $10^{4}$ cells were used to quantify the mass of iron oxide per cell. Solutions containing various concentrations of $\mathrm{FeCl}_{3}$ mixed with potassium thiocyanate $(2 \mathrm{M})$ were prepared for calibration. Solutions containing one volume of $\mathrm{HCl}(6 \mathrm{~N})$ mixed with 20 volumes of $\mathrm{H}_{2} \mathrm{O}_{2}$ were added to the cells to dissolve the iron oxide into $\mathrm{Fe}^{3+}$ ions and to denature all biological material. The cells were further lysed by sonication during 30 minutes at $30 \mathrm{~W}\left(0^{\circ} \mathrm{C}\right)$ and mixed with a solution of potassium thiocyanate $(2 \mathrm{M})$, which induces the formation of a complex composed of $\mathrm{Fe}^{3+}$ and $\mathrm{SCN}^{-}$. Quantification of iron oxide was estimated by absorption measurements at $480 \mathrm{~nm}$ (UVICON 923, Bio-Tek, Kontron Instrument, Italy). The untreated MDAMB-231 cells were used as reference. The experiments were carried out in triplicates. 
164 MDA-MB-231 cells were seeded on Petri dishes (Ø $30 \mathrm{~mm}$, density $\sim 5.10^{5}$ cells per Petri dish), grown 165 during 24 hours and incubated (or not) during 24 hours in the presence of suspensions of CM or IM at a 166 concentration of $142 \mu \mathrm{g} / \mathrm{mL}$. Cells were washed twice in PBS and fixed in $4 \%$ paraformaldehyde (PFA) 167 (Sigma) during 15 minutes at $4{ }^{\circ} \mathrm{C} . \mathrm{MDA}-\mathrm{MB}-231$ cells were washed twice more time in PBS and were 168 then stained with Perl's Prussian blue solution during 20 minutes at $37^{\circ} \mathrm{C}$ in an atmosphere containing 5 $169 \% \mathrm{CO}_{2}$. Perl's Prussian blue solution was prepared by mixing two solutions of equal volumes containing $1704 \%$ potassium ferrocyanide and $4 \% \mathrm{HCl}$. Staining (bright blue pigment: $\left.\mathrm{Fe}^{\mathrm{III}}\left[\mathrm{Fe}^{\mathrm{III}} \mathrm{Fe}^{\mathrm{II}}(\mathrm{CN})_{6}\right]_{3}\right)$ resulted 171 from the reaction between $\mathrm{Fe}^{2+}$ or $\mathrm{Fe}^{3+}$ ions coming from the dissolved magnetosomes and the 172 ferrocyanide ions. After having washed each Petri dish three times with PBS, Prussian blue staining was 173 observed using an optical microscope. The experiments were carried out in triplicates.

2.7 Scanning electron microscopy, transmission electron microscopy and optical microscopy studies of $175 M D A-M B 231$ cells incubated in the presence of either chains of magnetosomes or individual magnetosomes:

Scanning electron microscopy (SEM) studies were carried out using a FEG-SEM ultra 55 from Zeiss equipped with an energy dispersive X-ray analysis system (EDX). The samples studied by SEM contained MDA-MB-231 cancer cells incubated during 24 hours in the presence of IM or CM. The cells were deposited on top of a carbon grid covered with a carbon film and fixed with NOVAprep, produced 181 by Novacyt. Transmission electron microscopy (TEM) studies were also carried out using a JEOL $2100 \mathrm{~F}-\mathrm{FEG}$ operated at $200 \mathrm{kV}$. The samples studied by TEM contained $5 \mu \mathrm{l}$ of suspensions of IM or $183 \mathrm{CM}$ deposited on top of a carbon grid. Optical microscopy was also used to visualize precipitated 184 magnetosomes within MDA-MB 231 cells. For that, the cells were incubated in the presence (or not) of 185 suspensions containing either CM or IM. The cells were stained with Prussian blue, which precipitates in the presence of iron, producing a blue color in the micrographs, which reveals the presence of iron. 

tumors:

In whole magnetotactic bacteria, the chains of magnetosomes only occupy a small portion of the total

191 volume of a bacterium ( $0.02 \%)$. A TEM image of a typical AMB-1 magnetotactic bacterium is shown in Figure 1(a). Several chains of magnetosomes separated by more than $\sim 100 \mathrm{~nm}$ are contained within this bacterium. Large regions of the bacterium are not occupied by chains of magnetosomes. Because of the low density of the chains of magnetosomes within whole magnetotactic bacteria, suspensions containing whole magnetotactic bacteria are expected to yield a low in vivo heating efficiency. In addition, the administration of whole inactive magnetotactic bacteria in humans is not recommended due to the presence of potentially toxic biologic materials such as bacterial DNA or endototoxins, [21]. For these two reasons, whole inactive magnetotactic bacteria were not tested in this study. In order to minimize the risks of toxicity and to enhance the heating efficiency, the bacterial magnetosomes were isolated from the bacteria.

The first type of bacterial magnetosomes tested for magnetic hyperthermia consisted of chains of magnetosomes extracted from AMB-1 magnetotactic bacteria, CM. Figure 1(b) shows a TEM image of a suspension of $\mathrm{CM}$ deposited on top of a carbon grid. The extraction of the chains of magnetosomes from the bacteria yields an increase in the concentration of the chains of magnetosomes (Figures 1(a) and 1(b)). The magnetosome chains also appear to be longer than in whole bacteria. When chains of magnetosomes are extracted from the magnetotactic bacteria, they interact with each other in such a way that they form longer chains. This type of interaction yields a homogeneous distribution of CM within 208 the substrate (Figure 1(b)). To assess the stability of CM mixed in water, their zeta potential was 209 measured as a function of $\mathrm{pH}$ by dynamic laser light scattering (DLS) on a Nano-ZS (Red Badge) ZEN 2103600 device (Malvern Instruments, Malvern, UK). For a suspension of CM, which is homogenized by 211 sonication, Figure 2(a) shows that the variations of the zeta potential as a function of $\mathrm{pH}$ is very similar 
212 to that obtained for a non sonicated suspension of CM. This indicates the good stability of the 213 suspension of $\mathrm{CM}$ mixed in water. To examine if $\mathrm{CM}$ have kept the biological material surrounding 214 them after extraction, infra-red absorption measurements were carried out on CM. Figure 2(b) depicts 215 the infra-red absorption spectrum of a powder containing a lyophilized suspension of chains of 216 magnetosomes denatured and solubilized with $\mathrm{KBr}$. It shows two absorption peaks at $1650 \mathrm{~cm}^{-1}$ (peak 1 , 217 Figure 2(b)) and $1530 \mathrm{~cm}^{-1}$ (peak 2, Figure 2(b)), which arise from the Amide I and Amide II bands and 218 are due to the absorption of proteins, [21-23]. The peaks at $1250 \mathrm{~cm}^{-1}$ (peak 3, Figure 2(b)) and 1050 $219 \mathrm{~cm}^{-1}$ (peak 4, Figure 2(b)) can either be attributed to the absorption of lipopolysaccharide (LPS) or 220 phospholipids [23,24], both located within the magnetosome membrane, [20]. The peak at $580 \mathrm{~cm}^{-1}$ 221 (peak 5, Figure 2(b)) is attributed to maghemite, [25]. These results suggest that both the filament 222 binding the magnetosomes together, which is made of proteins such as MamJ or Mam K, [26-28], and 223 the bilayer surrounding the individual magnetosomes, which is composed of LPS and phospholipids, 224 [29], are contained within CM. After extraction, the magnetosome chains have kept the lipid bi-layer 225 surrounding each magnetosome and the filament binding the magnetosomes together.

226 To obtain suspensions of magnetosomes, which are similar to the chemically synthesized iron oxide 227 nanoparticles, $i$. e. not arranged in chains, IM have been prepared by heating a suspension of CM at 90 carbon grid are presented in Figures 1(c) and 1(d). It shows either assemblies of magnetosomes, which 230 are much more aggregated than the chains of magnetosomes (Figure 1(c)), or loops (Figure 1(d)). At pH $231=7$, Figure 2(a) shows that suspensions of IM possess very different values of their zeta potential 232 depending on whether or not they are mixed homogeneously by sonication. When IM are mixed 233 homogenously in solution, they possess a negative zeta potential of $\sim-35 \mathrm{mV}$ at $\mathrm{pH} \sim 7$, [30]. When 234 they are not sonicated, the $\mathrm{IM}$ zeta potential is $10 \mathrm{mV}$ at $\mathrm{pH} \sim 7$. The different values of the Zeta 235 potential suggest that IM easily form aggregates in solution and are therefore unstable in the absence of 236 sonication, [30]. The infra-red absorption spectrum of a powder containing a lyophilized suspension of 
IM integrated in a KBr matrix is presented in Figure 2(b). It shows Amide I and Amide II peaks (peaks 1 and 2, Figure 2(b)), suggesting that most of the proteins contained in the filament binding the magnetosomes together have been removed. The relatively strong peaks at $1050 \mathrm{~cm}^{-1}$ and $1240 \mathrm{~cm}^{-1}$ suggest that the bi-layer surrounding each magnetosome has not been significantly removed during the 241 heat treatment in the presence of a detergent.

\subsection{SAR of the different suspensions of bacterial magnetosomes:}

243 The SAR of suspensions containing IM and CM were measured in two situations in which the bacterial 244 magnetosomes were either able or unable to rotate under the application of an AMF, [16]. For the 245 bacterial magnetosomes mixed in water and able to rotate, Figures 3(a) and 3(b) show that the amount of 246 heat produced by the CM is larger than that produced by the IM. This behavior could be explained by 247 the fact that $\mathrm{CM}$ are less prone to aggregation and therefore rotate more easily than IM under the 248 application of an AMF. This analysis is further supported by the TEM image presented in Figure 1(b), 249 which clearly shows that CM do not aggregate by contrast to IM (Figure 1(c)). For the bacterial 250 magnetosomes mixed in water, the higher value of the SAR obtained for CM compared with IM could 251 therefore be explained by a contribution of the rotation to the heat production, which is more significant 252 for CM than for IM. By contrast, when CM and IM are fixed (either in a gel or on a solid substrate, 253 [16]), unable to rotate, mixed homogenously and exposed to the same AMF as above, IM produce a 254 relatively similar amount of heat than CM (Figure 3), [16]. These results suggest that when the rotation 255 of the magnetosomes is not taking part in the mechanism of heat production, which is most probably the 256 case in vivo, the quantity of heat generated by CM or IM is not only due to the magnetosome SAR but 257 also to the spatial distribution of the magnetosomes.

\subsection{Percentage of inhibition of HeLa and MDA-MB-231 cells incubated in the presence of CM or IM:}

259 To compare the anti-tumoral activity of CM with that of IM, CM and IM were incubated in the presence 260 of HeLa and MDA-MB-231 cells. The percentage of inhibition of cellular proliferation was then 
measured in the presence (or not) of an AMF. The results are presented for two suspensions of bacterial magnetosomes (CM or IM) with a concentration fixed at $0.125 \mathrm{mg} / \mathrm{ml}$. In the absence of application of an $\mathrm{AMF}$, the percentages of inhibition of MDA-MB-231 and HeLa cells incubated in the presence of $264 \mathrm{CM}$ or IM were as low as $2 \%$ and $10 \%$ (Figure 4(a)), respectively. When these cancer cells were 265 incubated in the presence of the $\mathrm{CM}$ and exposed to an AMF of frequency $198 \mathrm{kHz}$ and average 266 magnetic field strength of $20 \mathrm{mT}$ and $30 \mathrm{mT}$, the percentages of inhibition increased by factors of $\sim 3$ to $267 \sim 5$ for the HeLa cells and $\sim 7$ to $\sim 16$ for the MDA-MB-231 cells (Figure 4(a)). By contrast, when these 268 cancer cells were incubated in the presence of IM and exposed to the same AMF as above, the 269 percentage of inhibition of these cells remained almost identical (Figure 4(a)). A similar type of 270 behavior was observed when MDA-MB6231 and HeLa cells were incubated in the presence of CM and $271 \mathrm{IM}$ at higher iron oxide concentrations of $1 \mathrm{mg} / \mathrm{ml}$ (Suppl. Fig. 1(a)) and $0.5 \mathrm{mg} / \mathrm{ml}$ (Suppl. Fig. 1(b)). 272 These results indicate that under the application of an AMF, CM yield a higher percentage of cell 273 inhibition than IM.

3.4 Penetration of the chains of magnetosomes within the cancer cells under the application (or not) of an alternating magnetic field:

We examine if the different efficiencies observed between CM and IM are due to a different faculty of penetration within the cancer cells of these two types of bacterial magnetosomes. We first study if the application of an AMF induces the internalization of CM or IM within the cancer cells. To be able to estimate the magnetization of MDA-MB-231 cells, the latter had to be kept free and not fixed. The cells were incubated in the presence of the $\mathrm{CM}$ and $\mathrm{IM}$ and exposed to the same AMF as above. The cancer 281 cells were then washed with water to remove CM and IM located at their surface and the percentage of 282 magnetic cells was then measured. Following application of an AMF of frequency $198 \mathrm{kHz}$ during 5 to 28320 minutes, Figure 4(b) shows that the mass of maghemite per magnetic cell is always much higher for 284 the cells incubated in the presence of CM than for those incubated in the presence of IM. This result 285 suggests that under the application of an AMF, CM penetrate much more within the cancer cells than 
IM. Moreover, the high cellular magnetization, which can be reached in the presence of CM under the application of an AMF, could explain the high efficiency of $\mathrm{CM}$ for magnetic hyperthermia treatment of tumors.

We also study the internalization of $\mathrm{CM}$ and IM within the cancer cells as a function of the incubation time in the absence of an AMF. For that, the cells had to be fixed on top of a solid substrate. For a very short incubation time of less than 30 seconds, Figure 4(b) shows that neither CM nor IM penetrate within MDA-MB-231 cells. Suspensions containing CM and IM were then incubated in the presence of MDA-MB-231 cells for a longer incubation time of 24 hours. The cells were deposited on top of a carbon grid substrate and imaged under scanning electron microscopy. Figure 5(a) shows a portion of a typical MDA-MB-231 cell. Enlargements of two regions of the cell in which CM are observed are presented in Figures 5(b) and 5(c). Since CM are observed within intracellular vesicles, designated as V in Figure 5(b), which can be lysosomes or endosomes, CM are internalized within the cancer cell. The chain of magnetosome surrounded by a green box in Figures 5(c) and 5(d) contains two large magnetosomes at its end and several small magnetosomes at the middle. This type of magnetosome arrangement is clearly different from that observed for the magnetosome chains, which are not incubated in the presence of cancer cells (Figure 1(b)). It could be due to the degradation of the chains of magnetosomes by the cells following their internalization. Another reason why $\mathrm{CM}$ are internalized within the cells and not bound at the cell surface comes from the fact that the cells were washed prior to the observation by scanning electron microscopy. The presence of CM within the cells was further confirmed by EDX measurements, which revealed the presence of iron oxide in the region where CM were detected (Suppl. Fig. 3). By contrast to the behavior observed with CM, IM were not observed within the MDA-MB-231 cell (Suppl. Fig. 2). The EDX measurements confirmed this behavior (Suppl. 308 Fig. 3). They showed that iron was not detected in the cellular regions with presumably no 309 magnetosomes. 
310 The internalization of CM within the cancer cells for a sufficiently long incubation time of 24 hours was

311 further confirmed by optical microscopy. Figure 8 shows optical microscopy observations of MDA-MB-

312231 cells incubated in the absence of magnetosomes (Figure 8(a)), in the presence of CM during 24

313 hours (Figure 8(b)) or in the presence of IM during 24 hours (Figure 8(c)). For MDA-MB-231 cells

314 incubated in the absence of magnetosomes or in the presence of IM, no Prussian blue coloration was

315 observed within the cells. By contrast, for the MDA-MB-231 cells incubated in the presence of the CM,

316 Prussian blue coloration was observed within the cells. These results agree with those presented above

317 (Figures 5) and suggest that CM penetrate within the cells by contrast to IM, which remain located 318 outside of the cells.

3193.5 Explanation for the high efficiency of the chains of magnetosomes:

320 Altogether, these results indicate that CM penetrate more easily within the cancer cells than IM. While 321 the internalization within the cancer cells did not occur with IM, it was observed for CM in two 322 conditions, either when an AMF of $198 \mathrm{kHz}$ and average field strength of $20 \mathrm{mT}$ was applied during 5 to 32320 minutes and/or when the cells were incubated with CM for a sufficiently long time of 24 hours. The 324 internalization of CM within the cancer cells could occur by a mechanism of endocytosis or by effective 325 diffusion through the cell membrane. The mechanism of effective diffusion through the cell membrane 326 could be favored by a temperature increase taking place during the application of the AMF, which would 327 make the cell membrane permeable. This result agrees with previous studies, which showed that 328 negatively charged maghemite nanoparticles penetrate within cancer cells, [31]. Since intra-cellular 329 heating presumably efficiently damages cellular components, it may be a more efficient mechanism of 330 cell destruction than extra-cellular heating. The higher efficiency of CM compared with that of IM could 331 therefore be explained by the fact that CM internalize within the cancer cells by contrast to IM, which 332 mostly remain located outside of the cells. Poorly efficient internalization of IM may be related to the 333 more aggregated state of IM compared with that of $\mathrm{CM}$ as was observed in two cases, $i$. $e$. when 334 suspensions of CM and IM were deposited on top of a carbon grid (Figures 1(b) and 1(c)) and in vivo 
when suspensions of CM and IM were administered within tumors xeno-grafted under the skin of mice

336 and heated under the application of an AMF, [18]. A schematic summary showing the different 337 distributions of CM and IM in the presence of cancer cells is proposed in Figures 9(a) and 9(b). The 338 better internalization and more homogenous distribution of CM than IM could provide a reasonable 339 explanation for the higher anti-tumoral efficiency observed for CM than for IM, [18].

\section{Conclusion}

341 In conclusion, we have studied two types of bacterial magnetosomes extracted from AMB-1 342 magnetotactic bacteria, the magnetosomes organized in chains and those forming individual 343 magnetosomes detached from the chains by heat and chemical treatment. We have shown that chains of 344 magnetosomes were more efficient than individual magnetosomes in inhibiting cancer cell proliferation 345 under application of an alternating magnetic field. We have suggested that this increased efficiency was 346 related to much less particle aggregation for the magnetosome chains than for the individual 347 magnetosomes and as a consequence to a better faculty for the chains of magnetosomes than for the 348 individual magnetosomes to internalize within the cancer cells. This paper clearly highlights the

349 importance of nanoparticle distribution for efficient magnetic hyperthermia. It shows that the use of 350 nanoparticles with high SAR is not sufficient to yield efficient magnetic hyperthermia.

351 ACKNOWLEDGMENTS

352 François Guyot does not claim any inventive contribution in this work. We thank the company 353 NOVAcyt for giving us the NOVAprep product free of charge. 
Figure 1: (a) Transmission electron microscopy image of a typical whole inactive magnetotactic

360 bacterium deposited on top of a carbon grid. The magnetosomes are designated by blue arrows. (b)

361 Transmission electron microscopy image of suspensions of chains of magnetosomes, isolated from

362 magnetotactic bacteria, and deposited on top of a carbon coated copper grid. (c) Transmission electron

363 microscopy images of individual magnetosomes detached from the chains by heat and SDS treatment

364 showing a typical aggregate. (d) Transmission electron microscopy images of individual magnetosomes

365 detached from the chains by heat and SDS treatment showing a loop.

366 Figure 2: (a) Zeta potential of suspensions of chains of magnetosomes and individual magnetosomes as

367 a function of $\mathrm{pH}$. The measurements were carried out with suspensions containing bacterial 368 magnetosomes either mixed homogenously by sonication or not mixed. (b) Infrared absorption spectra 369 of powders containing lyophilized suspensions of CM or IM embedded within a $\mathrm{KBr}$ matrix.

370 Figure 3: (a) Specific absorption rate (SAR) of suspensions of chains of magnetosomes, which are able 371 (or not if embedded in a gel or deposited on a solid substrate) to rotate under the application of an 372 alternating magnetic field. (b) SAR of suspensions of individual magnetosomes, which are able (or not) 373 to rotate under the application of an alternating magnetic field.

374 Figure 4: (a) Percentage of inhibition of HeLa and MDA-MB-231 cells incubated in the presence of CM 375 and IM as a function of the magnetic field strength. (b) Mass of maghemite internalized within MDA376 MB-231 cells incubated in the presence of IM and CM and exposed to an alternating magnetic field of 377 frequency $198 \mathrm{kHz}$ and average field strength of $20 \mathrm{mT}$ during 5 to 20 minutes.

378 Figure 5: Scanning electron microscopy image of a MDA-MB-231 cell incubated in the presence of CM. 379 V designates a vesicle.

380 Figure 6: Confocal optical microscopic images of cancer cells stained with Prussian blue and incubated 381 in the absence of magnetosomes, (a), in the presence of CM, (b), and in the presence of IM, (c). 
382 Figure 7: Conceptual summary describing the effect of aggregation on the penetration of magnetosomes 383 within cancer cells. The magnetosomes are either CM, (a), or IM, (b).

384

385

386

387

388

389

390

391

392

393

394

395

396

397

398

399

400 
1. DeNardo, S.J., DeNardo, G.L., Natarajan, A., Miers, L.A., Foreman A.R., Gruettner C., Adamson 403 G.N., Ivkov R., 2007. Thermal Dosimetry Predictive of Efficacy of ${ }^{111}$ In-ChL6 Nanoparticle AMF404 Induced Thermoablative Therapy for Human Breast Cancer in Mice. J. Nucl. Med. 48, 437-444.

405 406 407 408 409 410

2. Kikumori, T., Kobayashi, T., Sawaki, M., Imai, T., 2009. Anti-cancer effect of hyperthermia on breast cancer by magnetite nanoparticle-loaded anti-HER2 immunoliposomes. Breast Cancer Res. Treat. 113, 435-441.

3. Johannsen, M., Gnevekow, U., Eckelt, L., Feussner, A., Waldöfner, N., Scholz, R., Deger, S., Wust, P., Loening, S.A., Jordan, A., 2005. Clinical hyperthermia od prostate cancer using magnetic nanoparticles: Presentation of a new interstitial technique. Int. J. Hyperthermia 21, 637-647.

4. Johannsen, M., Gnevekow, U., Thiesen, B., Taymoorian, K., Cho, C.H., Waldöfner, N., Scholz, R., Jordan, A., Loening, S.A., Wust, P., 2007. Thermotherapy of Prostate Cancer Using Magnetic Nanoparticles: Feasability, Imaging, and Three-Dimensional Temperature Distribution. European Urology 52, 1653-1662.

5. Kawai, N., Ito, A., Nakahara, Y., Futakuchi, M., Shirai, T., Honda, H., Kobayasi, T., Kohri, K., 2005. Anticancer Effect of Hyperthermia on Prostate Cancer Mediated by Mediated by Magnetite Cationic Liposomes and Immune-Response Induction in Transplanted Syngeneic Rats. The Prostate. 64, 373381.

6. Kawai, N., Futakuchi, M., Yoshida, T., Ito, A., Sato, S., Naiki, T., Honda, H., Shirai, T., Kohri, K., 2008. Effect of Heat Therapy Using Magnetic Nanoparticles Conjugated With Cationic Liposomes on Prostate Tumor in Bone. The Prostate. 68, 784-792.

7. Maier-Hauff, K., Ulrich, F., Nestler, D., Niehoff, H., Wust, P., Thiesen, B., Orawa, H., Brudach, V., Jordan, A., 2011. Efficacy and safety of intratumoral thermotherapy using magnetic iron-oxide 
nanoparticles combined with external beam radiotherapy on patients with recurrent glioblastoma multiforme. J. Neurooncol. 103, 317-324.

8. Zhao, Q., Wang, L., Cheng, R., Mao, L., Arnold, R.D., Howerth, E.W., Chen, Z.G., Platt, S., 2012. Magnetic Nanoparticle-Based Hyperthermia for Head and Neck Cancer in Mouse Models. Theranostics. 2, 113-121.

9. Hergt, R., Dutz. S., Müller, R., Zeisberger, M., 2006. Magnetic hyperthermia: nanoparticle magnetism and material development for cancer therapy. J. Phys.: Condens. Matter. S2919-S2934.

10. Hergt, R., Dutz, S., 2007. Magnetic particle hyperthermia-biophysical limitations of a visionary tumour therapy. J. Magn. Magn. Mat. 311, 187-192.

11. Hergt, R., Dutz, S., Röder, M., 2008. Effects of size distribution on hysteresis losses of magnetic nanoparticles for hyperthermia. J. Phys.: Condens. Matter. 385214.

12. Bordelan, D.E., Cornefo, C., Grüttner, C., Wesphal, F., Deweese, T.L., Ivkov, R., 2011. Magnetic nanoparticle heating efficiency reveals magneto-structural differences when characterized with wide ranging and high amplitude alternative magnetic fields. J. Appl. Phys. 109, 124904.

13. Ivkov, R., DeNardo, S.J., Daum, W., Foreman, A.R., Goldstein, R.C., Nemkov, V.S., DeNardo V., 2005. Application of High Amplitude Alternating Magnetic Fields for Heat Induction of Nanoparticles Localized in Cancer. Clin. Cancer Res. 11, 7093s-7103s.

14. Hergt, R., Hiergeist, R., Zeisberger, M., Schüler, D., Heyen, U., Hilger, I., Kaiser, W. A., 2005. Magnetic properties of bacterial magnetosomes as potential diagnostic and therapeutic tools. J. Magn. Magn. Matter. 293: 80-86.

15. Timko, M., Dzarova, A., Kovac, J., Skumiel, A., Józefcak, A., Hornowski, T., Gojżewski, H., Zavisova, V., Koneracka, M., Sprincova, A., Strbak, O., Kopcansky, P., 2009. Tomasovicova N, Magnetic properties and heating effect in bacterial magnetic nanoparticles. J. Magn. Magn. Matter. $321,1521-1524$. 
448 16. Alphandéry, E., Faure, S., Chebbi, I., 2011. Treatment of cancer or tumor induced by the release 449 of heat generated by various chains of magnetosomes extracted from magnetotactic bacteria and $450 \quad$ submitted to an alternative magnetic field. Int. Patent No. 061259.

451 17. Alphandéry, E., Carvallo, C., Menguy, N., Chebbi, I., 2011. Chains of Cobalt Doped 452 Magnetosomes Extracted from AMB-1 Magnetotactic Bacteria for Application in Alternative 453 Magnetic Field Cancer Therapy. J. Phys. Chem. C. 115, 11920-11924.

454 18. Alphandéry, E., Faure, S., Seksek, O., Guyot, F., Chebbi, I., 2011. Chains of Magnetosomes 455 Extracted from AMB-1 Magnetotactic Bacteria for Application in Alternative Magnetic Field Cancer 456 Therapy. ACSnano. 5, 6279-6296.

457 19. Mosmann, T., 1938. Rapid Colorimetric Assay for Cellular Growth and Survival: Application to 458 Proliferation and Cytotoxicity Assays. J. Immunol. Methods. 65, 55-63.

459 20. Yoshino, T., Hirabe, H., Takahashi, M., Kuhara, M., Takeyama, H., Matsunaga, T., 2008. 460 Magnetic Cell Separation Using Nano-Sized Bacterial Magnetic Particles With Reconstructed 461 Magnetosome Membrane. Biotechnology and Bioengineering. 101, 470-477.

462 21. Diem, M., Bodydston-White, S., Chiriboga, L., 1999. Infrared Spectroscopy of Cells and 463 Tissues: Shining Light onto a Novel Subject. Applied Spectroscopy. 53, 148A-161A.

464 22. Han, L., Li, S.Y., Yang, Y., Zhao, F.M., Huang, J., Chang, J., 2008. Research on the Structure 465 and Performance of Bacterial Magnetic Nanoparticles. J. Biomat. Appl. 22, 433-448.

466 23. Song, H.P., Li, X.G., Sun, J.S., Xu, S.M., Han, X., 2008. Application of a magnetotactic 467 bacterium, Stenotrophomas sp. to the removal of $\mathrm{Au}(\mathrm{III})$ from contaminated wastewater with a 468 magnetic separator. Chemosphere. 72, 616-621.

469 24. Abramson, M.B., Norton, W.T., Katzman, R., 1965. Study of Ionic Structures in Phospholipids 470 by Infrared Spectra. The Journal of Biological Chemistry. 240, 2389-2395. 
471 25. Salazar, A., Morales, A., Marquez, M., 2011. Characterization of natural microcosms of 472 estuarine magnetotactic bacteria. Dyna. 72-80.

473 26. Draper, O., Byrne, M.E., Li, Z., Keyhani, S., Barrozo, J.C., Jensen, G., Komeili, A., 2011. Mam $474 \mathrm{~K}$, A bacterial actin, forms dynamic filament in vivo that are regulated by the acidic proteins MamJ 475 and Lim J. Mol. Microbiol. 82, 342-354.

476 27. Scheffel, A., Gruska, M., Faivre, D., Linaroudis, A., Plitzko, J., Schüler, D., 2006. An acidic 477 protein aligns magnetosomes along a filamentous structure in magnetotactic bacteria. Nature. 440, $478 \quad 110-114$

479 28. Villanueva, A., Canete, M., Roca, A.G., Calero, M., Veintemillas-Verdaguer, S., Serna, C.J., Del 480 Puerto Morales, M., Miranda, R., 2009. The influence of surface functionalization on the enhanced 481 internalization of magnetic nanoparticles in cancer cells. Nanotechnology. 20, 115103.

482 29. Xie, J., Chen, K., Chen, X., 2009. Production, Modification and Bio-Applications of Magnetic 483 Nanoparticles Gestates by Magnetotactic Bacteria. Nano. Res. 2, 261-278.

484 30. Sunderland, C.J., Steiert, M., Talmadge, J.E., Derfus, A.M., Barry, S.E., 2006. Targeted 485 nanoparticles for detecting and treating cancer. Drug Dev. Res. 67, 70-93.

486 31. Wilhelm, C., Billotey, C., Roger, J., Pons, J.N., Bacri, J.C., Gazeau, F., 2003. Intracellular 487 uptake of anionic superparamagnetic nanoparticles as a function of their surface coating. $488 \quad$ Biomaterials. 24, 1001-1011. 


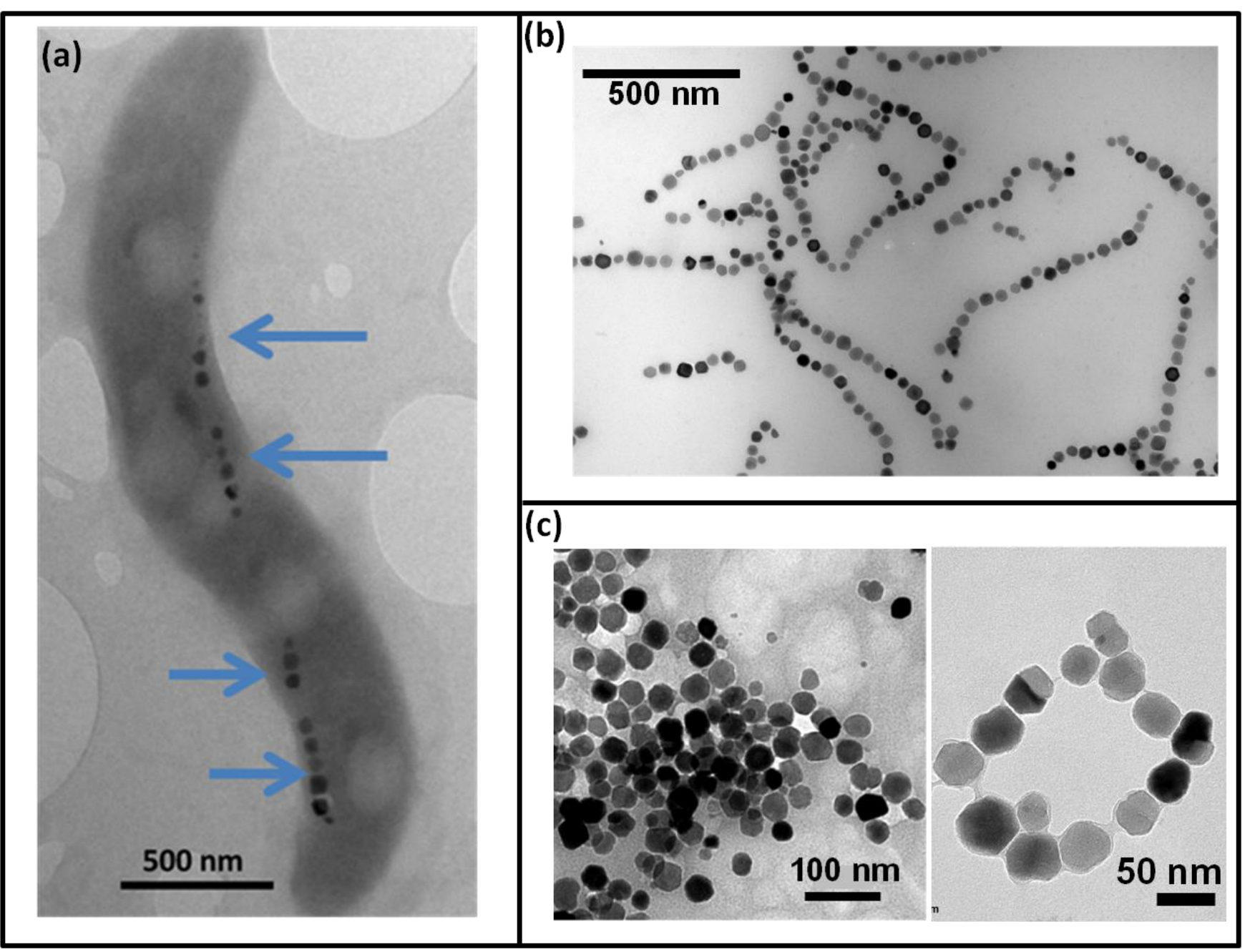

FIG. 1

498

499

500

501

502 


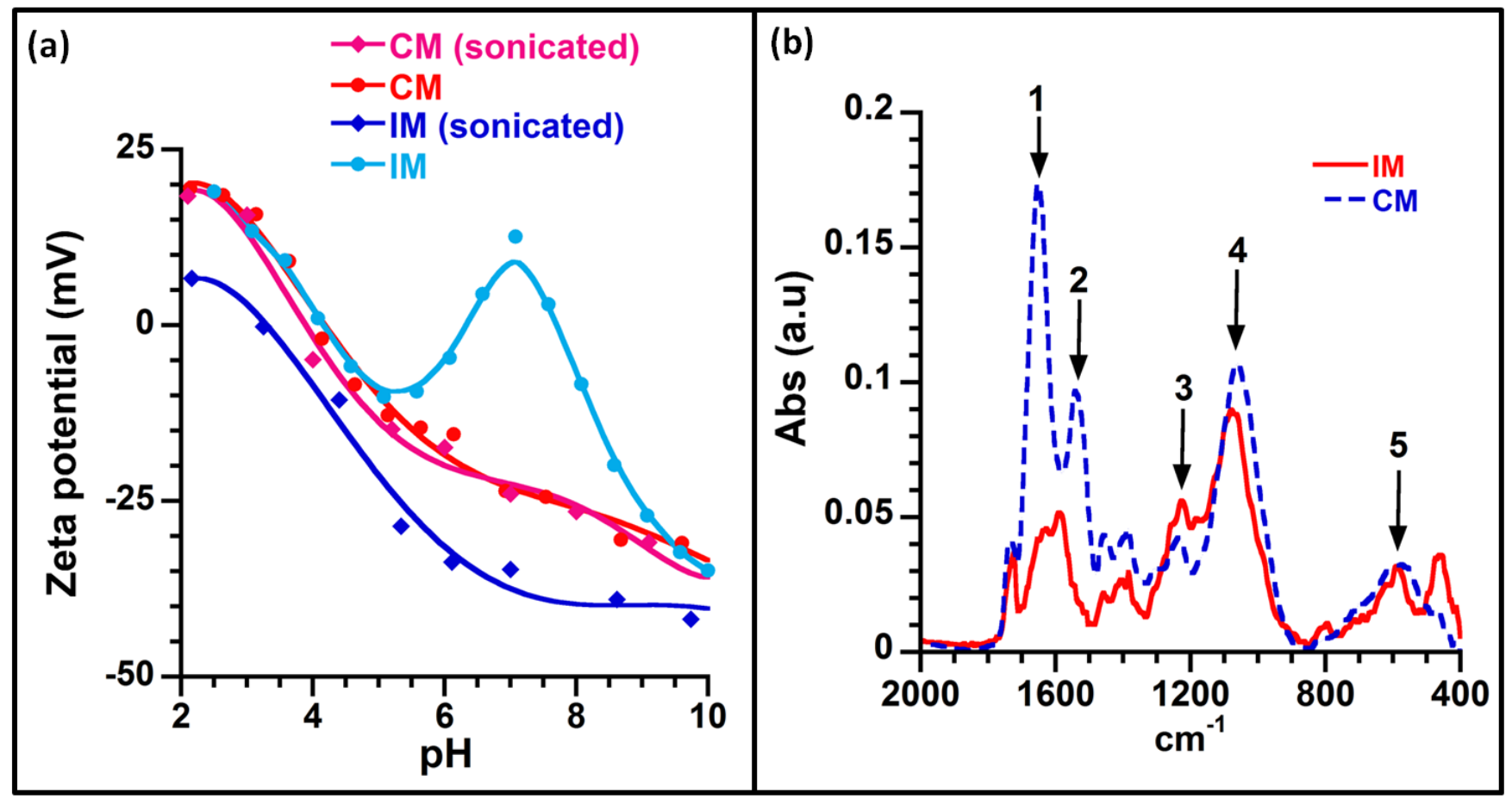

FIG. 2 


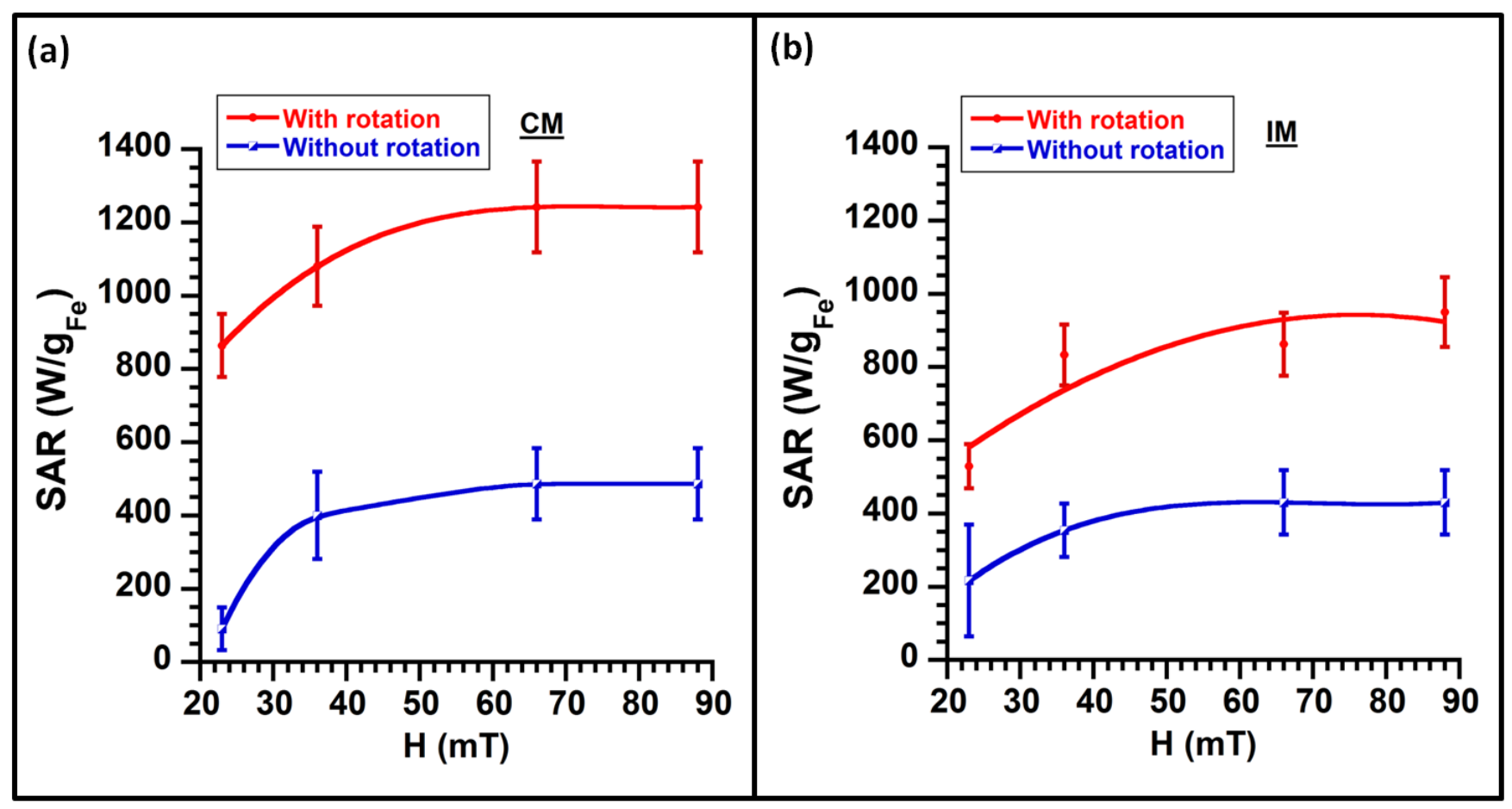

FIG. 3

518 


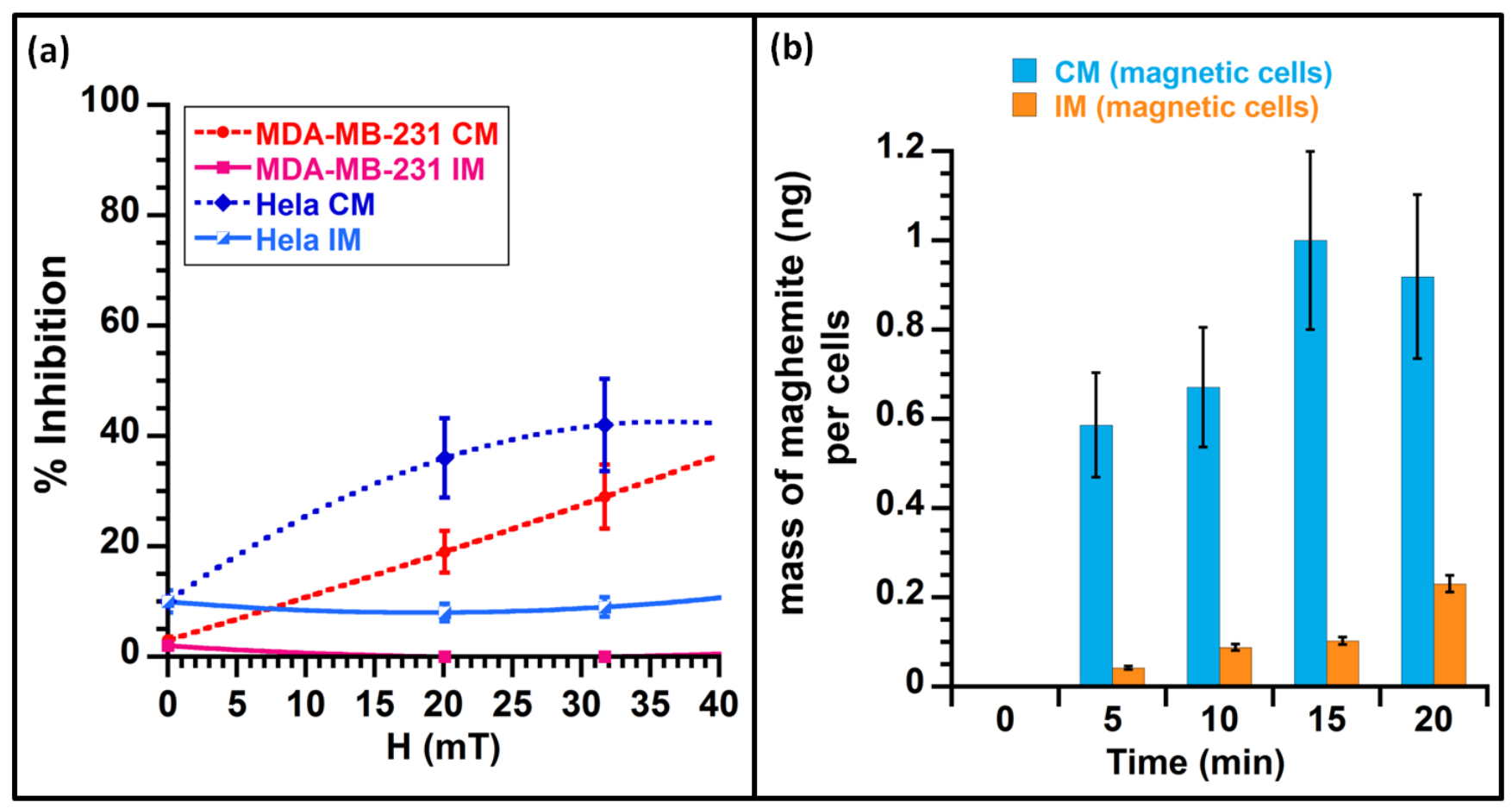

FIG. 4 
536

537

538

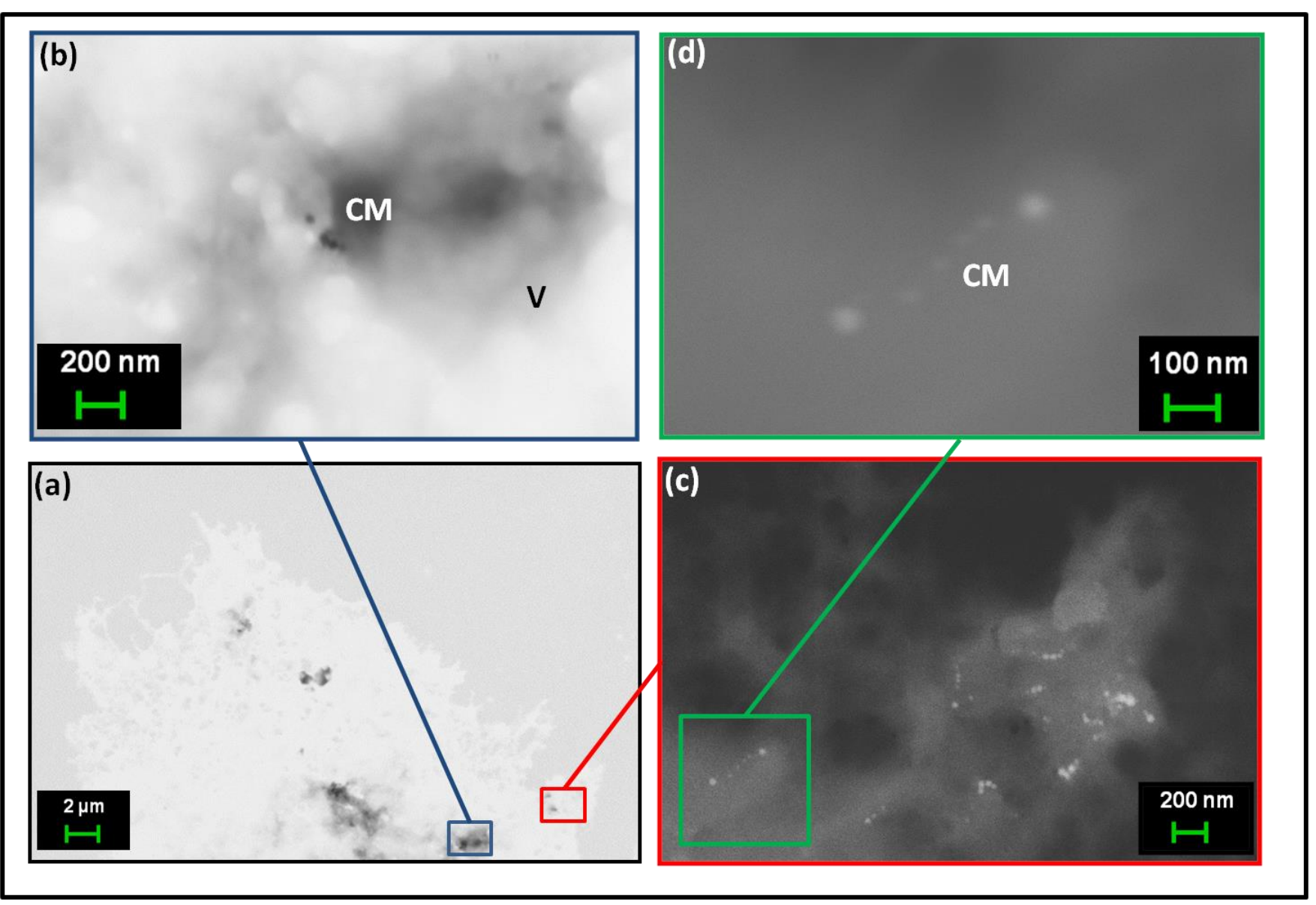

539

FIG. 5

540

541

542

543

544

545

546 


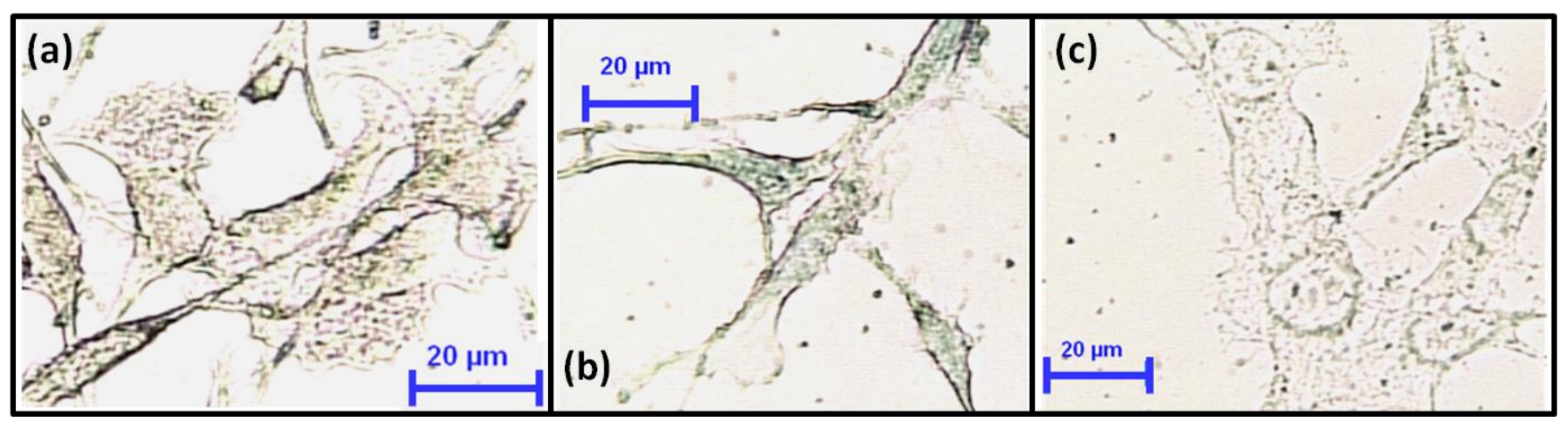

FIG. 6

551

552

553

554

555

556

557

558

559 


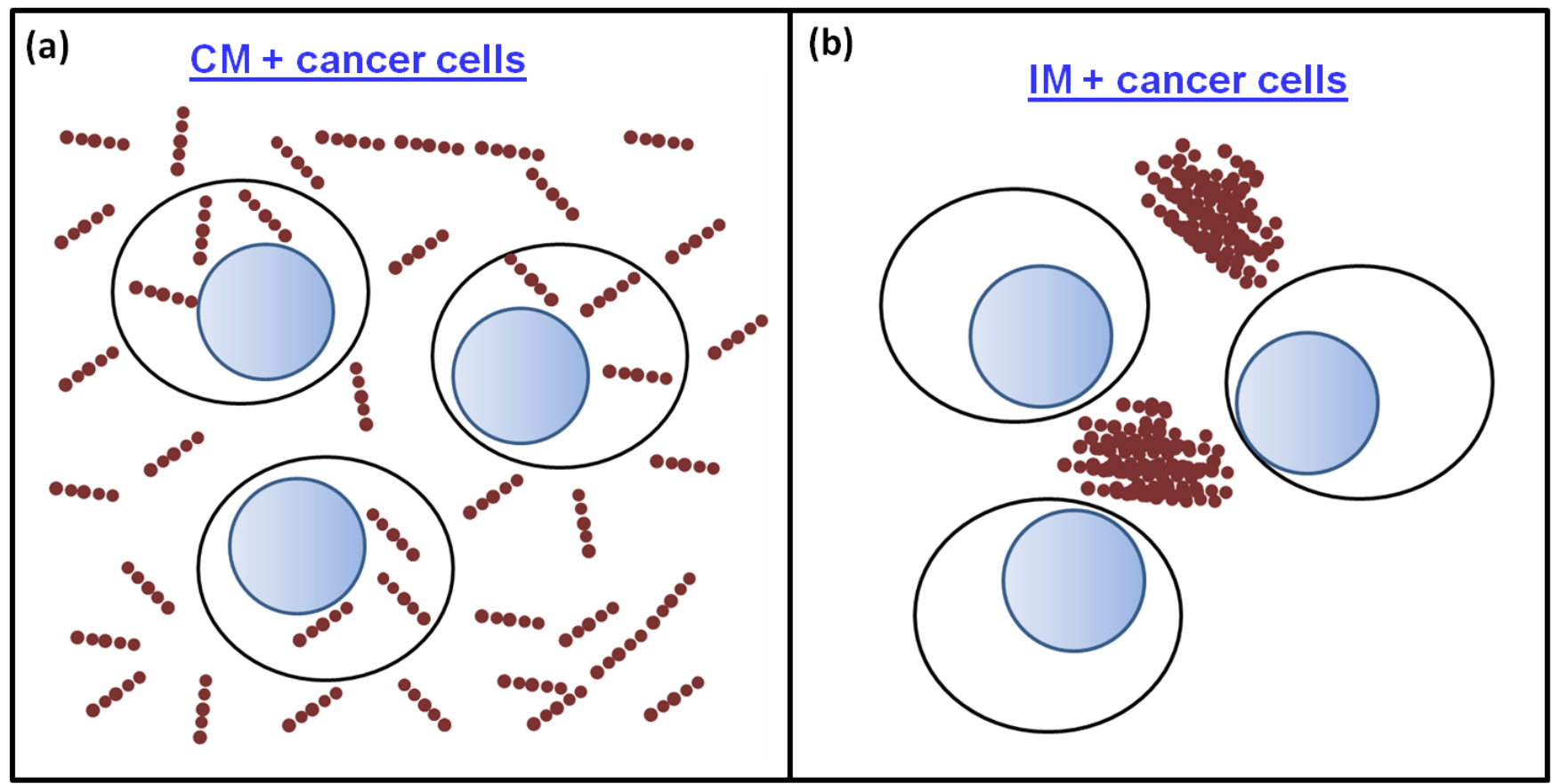

FIG. 7 